\title{
Investigation of the short-time variability of tropical tropospheric
}

\section{ozone}

\author{
T. Randriambelo ${ }^{1}$, J.-L. Baray ${ }^{1}$, S. Baldy ${ }^{1}$, A. M. Thompson ${ }^{2}$, S. Oltmans ${ }^{3}$, and P. Keckhut ${ }^{4}$ \\ ${ }^{1}$ Laboratoire de Physique de l'Atmosphere, UMR-CNRS 8105,15 Avenue René Cassin, Reunion Island 97715, France \\ ${ }^{2}$ NASA Goddard Laboratory for Atmosphere, GSFC, Greenbelt, MD, USA \\ ${ }^{3}$ NOAA, Climate Monitoring and Diagnostics Laboratory, Boulder, Colorado, 325 Broadway, Boulder, Colorado, USA \\ ${ }^{4}$ Service d'Aeronomie, BP 3, 91371 Verriéres-le-Buisson Cedex Paris, France
}

Received: 10 July 2002 - Revised: 10 February 2003 - Accepted: 28 February 2003

\begin{abstract}
Since 1998, a ground-based tropospheric ozone lidar has been running at Reunion Island and has been involved with a daily measurement campaign that was performed in the latter part of the biomass burning season, during November-December 1999. The averaged ozone profile obtained during November-December 1999 agrees well with the averaged ozone profile obtained from the ozonesondes launch at Reunion during November-December (19922001). Comparing weekly sonde launches (part of the Southern Hemisphere Additional Ozonesondes: SHADOZ program) with the daily ground-based lidar observations shows that some striking features of the day-to-day variability profiles are not observed in the sonde measurements. Ozone profiles respond to the nature of disturbances which vary from one day to the next.
\end{abstract}

The vertical ozone distribution at Reunion is examined as a function of prevailing atmospheric circulation. Back trajectories show that most of the enhanced ozone crossed over biomass burning and convectively active regions in Madagascar and the southern African continent. The analyses of the meteorological data show that ozone stratification profiles are in agreement with the movement of the synoptic situations in November-December 1999. Three different sequences of transport are explained using wind fields. The first sequence from 23 to 25 November is characterized by northerly transport; during the second sequence from 26 to 30 November, the air masses are influenced by meridional transport. The third sequence from 2 to 6 December is characterized by westerly transport associated with the subtropical jet stream. The large, standard deviations of lidar profiles in the middle and upper troposphere are in agreement with the upper wind variabilities which evidence passing ridge and trough disturbances. During the transition period between the dry season and the wet season, multiple ozone sources including stratosphere-troposphere exchanges, convection and biomass burning contribute to tro-

Correspondence to: T. Randriambelo

(randriam@univ-reunion.fr) pospheric ozone at Reunion Island through sporadic events characterized by a large spatial and temporal variability.

Key words. Atmospheric composition and structure (troposphere-composition and chemistry) - Meteorology and atmospheric dynamics (climatology; tropical meteorology)

\section{Introduction}

In the southern tropics, photochemical formation from biomass burning emissions is an important source of ozone. International measurement programs like SAFARI (Southern African Fire-Atmosphere Research Initiative) and TRACE A (Transport and Atmospheric Chemistry near Equator Atlantic) (Andreae et al., 1996), TROPOZ (TROPospheric OZone) (Marenco et al., 1990), and DECAFE (Dynamique Et Chimie de l'Atmosphère en Forêt Equatoriale) (Lacaux et al., 1995) have characterised the role of pollutant emissions over Africa, one of the principal regions of biomass burning in the Southern Hemisphere. One of the objectives of these campaigns was to study atmospheric photochemistry and tropospheric circulation patterns in relation to the enhanced ozone concentration observed over the southern Africa continent and the adjacent oceans (Fishman et al., 1990; Thompson et al., 1996). The contribution of the stratospheric air is also observed in the southern Africa during meteorological disturbances, such as westerly waves, cut-off low and frontal zones (Bachmeier and Fuelberg, 1996; Diab et al., 1996a, b; Fuelberg et al., 1996; and Garstang et al., 1996). Meteorological analysis demonstrates that a large part of the flow from the African continent, evaluated on trajectory statistics, could be advected towards the Indian Ocean (Garstang et al., 1996). Consequently, Reunion Island $\left(21^{\circ} \mathrm{S}, 55^{\circ} \mathrm{E}\right)$ should be a well-suited location for the study of the transport of aerosols and trace gases in plumes from southern Africa.

Since 1992, the ozone profiles observed at Reunion Island support these findings. Analyses of ozonesondes showed 
the influence of different contamination mechanisms from biomass burning by-products (Baldy et al., 1996; Taupin et al., 1999, 2001) and stratosphere troposphere exchange (Baray et al., 1998). The climatology using ozonesondes and satellite observations of fire and convective areas pinpoint the impact of different mechanisms (Randriambelo et al., 2000). A case study of extremely high ozone mixing ratio, where stratosphere-troposphere exchange and anthropogenic emissions work together, has been reported (Randriambelo et al., 1999).

In the southern Africa, meteorological conditions exert a major influence on the horizontal and vertical distributions of aerosols and trace gases (Fuelberg et al., 1996; Garstang et al., 1996). Daily measurements at Namibia give evidence of the influence of anticyclones and troughs on the vertical distribution of ozone (Diab et al., 1996a). Over the Pacific persistent layers of high ozone from biomass burning are evident in MOZAIC (Measurement of Ozone and Water Vapor by Airbus In-Service Aircraft) data and also in soundings (Newell et al., 1999; Stoller et al., 1999). Thus, it is of special interest to study the influence of meteorological conditions on vertical ozone distributions in the Indian Ocean. Because of the low frequency of in situ measurements (weekly or less), it has been hard to characterize the day-to-day variability of tropospheric ozone. Several studies based on INDOEX measurements (De Laat et al., 1999; Zachariasse et al., 2000) have dealt with short-term variability of ozone though mainly north of the equator and in the Indian Ocean, when the convective activity is maximum, and biomass burning in Southern Africa is minimum (FebruaryApril) (Cahoon et al., 1992; Barbosa et al., 1999; Arino et al., 2001).

From these studies, and with the SHADOZ program providing regular ozone profiles for ten stations in the Southern Hemisphere (Thompson et al., 2003a), the climatological impact of biomass burning, including its horizontal extent and timing has been documented. The "curtain figures" of the ozone mixing ratio show that week-to-week variability is intense at most SHADOZ stations (Thompson et al., 2003b). In particular, alternation of clean and polluted layers is observed during the biomass burning season. Since Reunion Island is both influenced by stratosphere troposphere exchanges and biomass burning, Reunion station data is expected to be characteristic of SHADOZ data set variability. The question still to be answered is whether biomass burning leads to an enhancement of the background ozone or to sporadic enhancements of ozone, with a large variability on a day-to-day time scale. This day-to-day monitoring could be achieved by complementing SHADOZ data by lidar measurement campaigns.

Since 1998, a ground-based tropospheric ozone lidar has been running at Reunion Island University. A first intensive measurement campaign performed during austral winter (July 1998) was used to study planetary scale tropopause folds (Baray et al., 2000). The objective of the present paper is to analyze a second lidar campaign (one lidar sounding per night) performed in November-December 1999. This pe- riod corresponds to the transition between the dry season and the rainy season, where traditional intensive forest fires from shifting cultivation are the practice in Madagascar (Randriambelo et al., 1998). This new data set is used to investigate the day-to-day variability of tropospheric ozone in the context of meteorological conditions.

\section{Data}

This study is principally based on remotely sensed data obtained by a ground-based tropospheric ozone lidar at Reunion Island. Measurements of tropospheric ozone are made by differential absorption in the ultraviolet $(289-316 \mathrm{~nm})$. These wavelengths are obtained by stimulated Raman scattering of the fourth harmonic of the Nd-Yag laser beam in a high-pressure deuterium cell. The reception system includes a mosaic of 4 parabolic mirrors, which collect the backscattered signal. The signal is then transmitted by optical fibers. Spectral separation of the 289 and 316 beams is obtained with a spectrometer that includes a Czerny-Turner holographic grating of 3600 lines $/ \mathrm{mm}$. Then each beam is redirected toward non-cooled Hamamatsu R1527P PMTs (Photomultiplier tubes) by concave mirrors. The signal processing electronic chain and data processing are similar to those used at the Observatoire de Haute Provence ozone lidar station (Ancellet et al., 1991). Technical details of the system and validation measurements (comparisons with electrochemical concentration cell ozone soundings) are given in Baray et al. (1999).

The lidar altitude ranges from $3 \mathrm{~km}$ to around $15 \mathrm{~km}$, with the upper limit depending on the meteorological conditions and ozone amount, and on the alignment of the reception system. The altitude resolution of the final ozone profiles is $15 \mathrm{~m}$ for the analog signal (from 3 to $6-7 \mathrm{~km}$ ), and $150 \mathrm{~m}$ for the photon-counting signal (from 6-7 km to the upper limit). Lidar measurements were made on almost all the days from 23 November to 6 December 1999. The acquisition time is from 30 to $45 \mathrm{~min}$ for each profile, generally beginning at night under clear sky conditions (near 16:00-17:00 UT which corresponds to 20:00-21:00 LT). One profile per night corresponding to the averaged acquisition is considered.

One ozone sounding was performed during this intensive campaign (on 2 December 1999), providing a profile of ozone mixing ratio (measured by electro-chemical concentration cell ozone), temperature and relative humidity (measured by a Vaisala RS 80-15 radiosonde). The vertical resolution of the ozonesonde is around $50 \mathrm{~m}$ and launches are generally made early in the morning, (near 07:00 UT). The characteristics of the ozonesonde are detailed elsewhere (Baldy et al., 1996).

These in situ data are augmented by the global product of satellite TOMS data (Total Ozone Mapping Spectrometer), and by ECMWF analysis data (European Centre for Meteorological Weather Forecast). In 1999, the TOMS spectrometer was on board the Earth Probe observation satellite, providing a global coverage of the total ozone column with a 
resolution of 1.25 degree in longitude and 1 degree in latitude. ECMWF data used are T213 spherical harmonics, interpolated to a horizontal resolution of 1 degree in longitude and latitude, and 15 vertical levels between 1000 and $10 \mathrm{hPa}$. Back trajectories calculated from ECMWF data are used. The validation of kinematic back trajectories has been addressed elsewhere (Baldy et al., 1996; Randriambelo et al., 2000).

\section{Atmospheric circulation during November - Decem- ber}

\subsection{Dynamical context}

Southern Africa and adjacent Atlantic and Indian Oceans are located in the region of large-scale subsidence occurring between the Hadley and Ferrel cells of the Southern Hemisphere general circulation. Subsidence is the dominant features of the circulation. The circulation patterns in the southern Africa and the adjacent oceans are described by PrestonWhyte and Tyson (1988). The main elements affecting the day-to-day weather in southern Africa and the Indian ocean owe their origin to subtropical, tropical and temperate features of the general circulation. The subtropical control is effected through the semi-permanent south Indian anticyclone, the continental high and the south Atlantic anticyclone. The south Atlantic and Indian anticyclones vary significantly in position throughout the year in their latitudinal and zonal position. On the scale of days, the south Atlantic high may ridge eastward and to the south continent. Extended ridging leads to breaking of a separate high, which drifts eastward into the Indian Ocean before being subsumed into the South Indian high. The tropical control is effected through tropical easterly flow in the southern Africa and the low level easterly jet stream equatorward of Reunion Island. The temperate control is exerted through travelling perturbations in the westerlies.

\subsection{Circulation at surface level}

The wind fields at $925 \mathrm{hPa}$ show that several prominent circulation features are present in the study region from 23 November to 6 December 1999 (Fig. 1). The south Atlantic anticyclone position varies during the period. Two ridging south Atlantic anticyclones are observed near $40 \mathrm{~S}, 22 \mathrm{E}$ for the 24 November (Fig. 1a) and near $37 \mathrm{~S}, 35 \mathrm{E}$ for the 30 November (Fig. 1c). They moved eastward to reach the south Indian anticyclone after around two days. The westerly waves associated with a trough are regularly observed in the edge of the southern Africa and move towards the Indian Ocean. These westerly waves are associated with a cold front that passes over South Africa. During the period NovemberDecember 1999, the frontal zone does not reach Reunion Island.

Reunion Island is under the influence of the south Indian anticyclone and the easterly low-level jet stream (Fig. 1). Table 1 shows that the position of the south Indian anticyclone a)

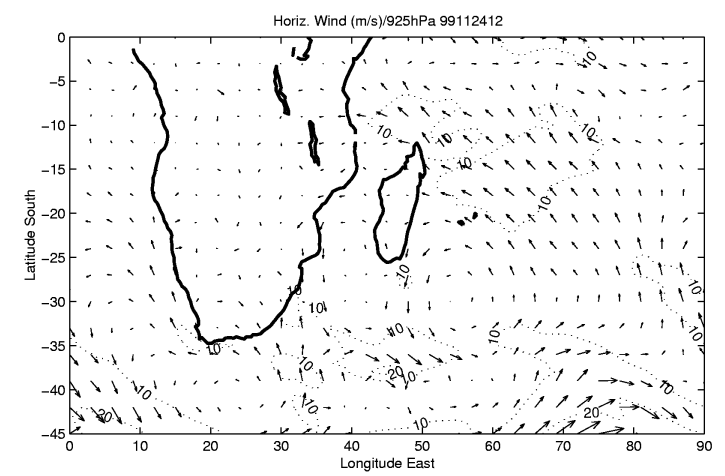

b)

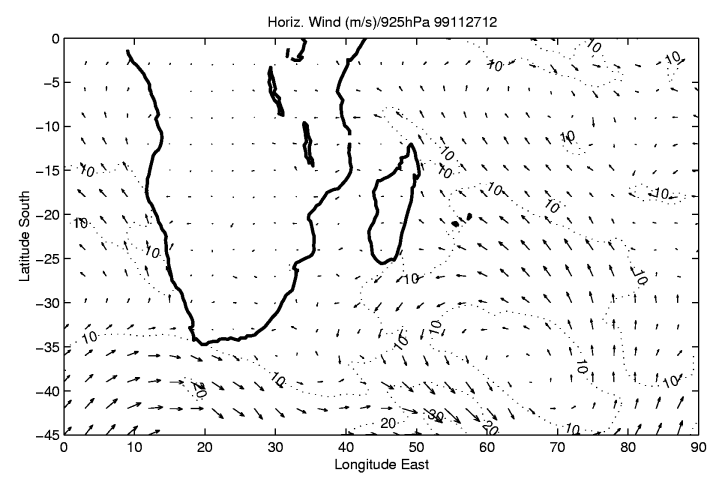

c)

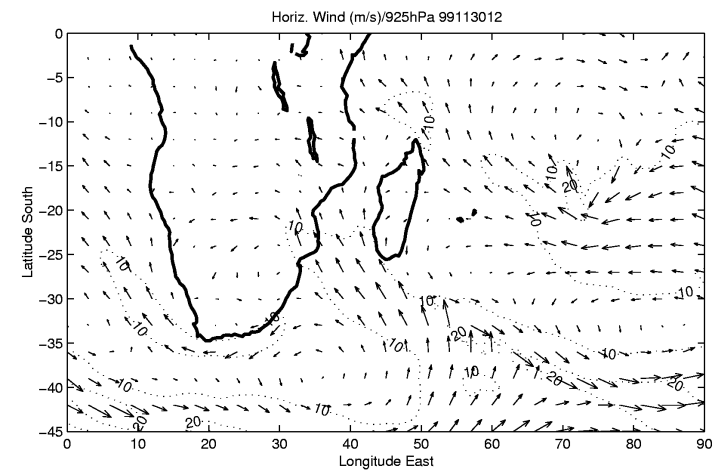

d)

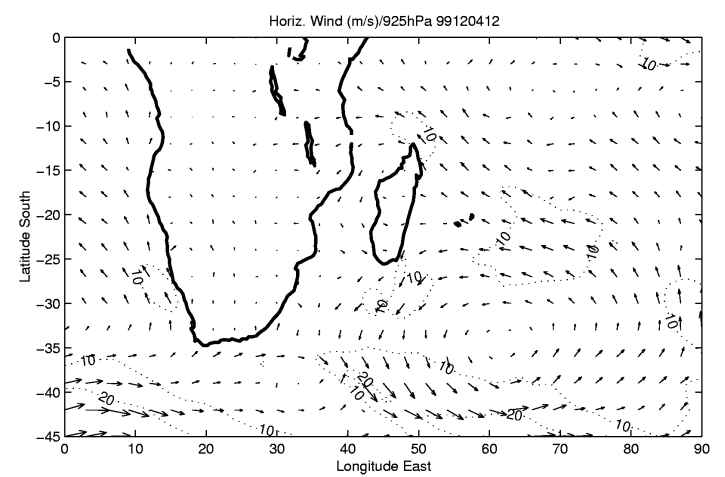

Fig. 1. Wind fields at $925 \mathrm{hPa}$ from ECMWF data showing the circulation patterns at low level in the southern Africa and the adjacent oceans for (a) 24 November, (b) 27 November, (c) 30 November, and (d) 4 December. 
Table 1. Location of the center of the south Indian anticyclone and the zonal winds as function of the day at $925 \mathrm{hPa}$ and at $250 \mathrm{hPa}$

\begin{tabular}{rrrrr}
\hline Day & latitude & longitude & $925 \mathrm{hPa}(\mathrm{m} / \mathrm{s})$ & $250 \mathrm{hPa}(\mathrm{m} / \mathrm{s})$ \\
\hline 23 & 28 & 58 & 3,40 & 14,83 \\
24 & 28 & 55 & 5,03 & 17,9 \\
25 & 25 & 43 & 5,10 & 8,86 \\
26 & 42 & 52 & 5,55 & 5,77 \\
27 & 37 & 66 & 6,56 & 10,34 \\
28 & 32,5 & 64 & 6,40 & 8,52 \\
29 & 34 & 73 & 4,98 & 7,47 \\
30 & 31 & 85 & 1,13 & 1,69 \\
1 & 37 & 45 & 2,94 & 16,43 \\
2 & 37 & 48 & 4,19 & 22,72 \\
3 & 37 & 48 & 3,66 & 24,5 \\
4 & 36 & 61 & 3,62 & 24,13 \\
5 & 35 & 67 & 2,08 & 15,91 \\
6 & 35 & 72 & 2,61 & 14,49 \\
\hline
\end{tabular}

varies along latitudinal and longitudinal positions. The south Indian anticyclone moves towards the east, pushed by the passage of the regular frontal zones. The Indian Ocean anticyclone is displaced in its maximum eastward position for 30 November and 6 December (Fig. 1c, Table 1). The daily wind fields at surface level show three different sequences of circulation. First, from 23 to 25 November, the latitudinal variation is weak and corresponds to the end of the addition of the ridging south Atlantic anticyclone and the south Indian anticyclone. For the second period from 26-30 November, the latitudinal variation of the south Indian anticyclone is strong. For the third period from 1 to 6 December, the south Indian anticyclone is stronger than the first period and its latitudinal variation is weak.

\subsection{Circulation at high altitude}

The wind fields at $250 \mathrm{hPa}$ show that the upper level anticyclone and the westerly waves are observed in the southern Africa and the adjacent oceans (Fig. 2). In the Indian Ocean, as at surface level, the winds fields present three different sequences of circulation. First, from 23-25 November, the winds come from the north (Fig. 2a). The second period of 26-30 November is under the influence of a strong curvature of the westerly waves and the winds come from the south (Fig. 2b). The third period from 1 to 6 December is associated with a weak curvature of the jet stream (Fig. 2d). The beginning of this period is influenced by the northerly winds and ends with the displacement of the jet stream towards the east.

The upper wind fields observed at Reunion Island also give evidence of an important variability (Fig. 3). At ground level, the trade-wind regime appears regular. Above $800 \mathrm{hPa}$, the variability depends on location of the subtropical jet stream, and the influence of the tropical convection. The upper wind variabilities are in agreement with the different sequences of a)

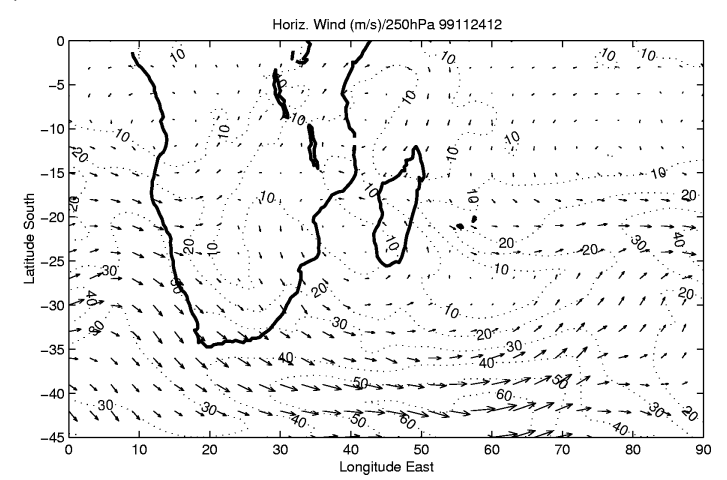

b)

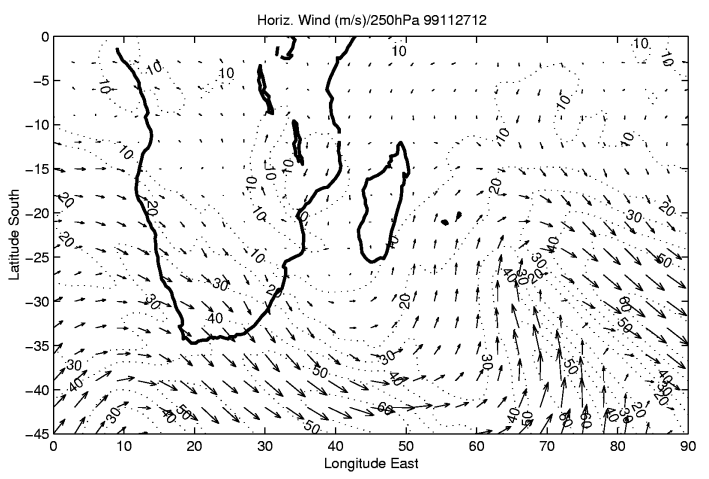

c)

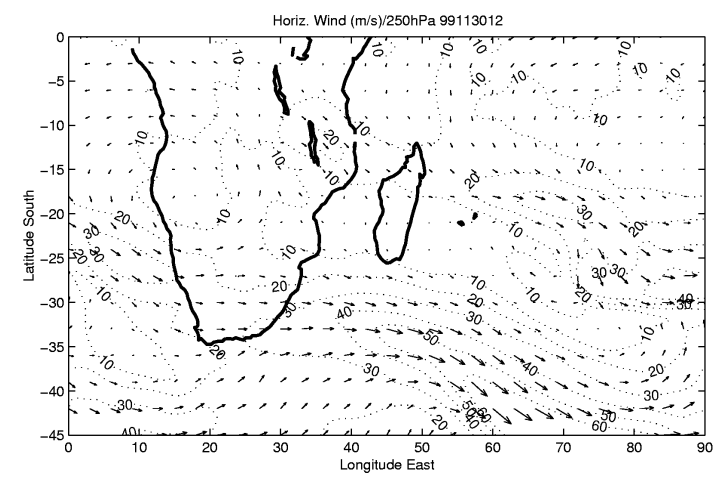

d)

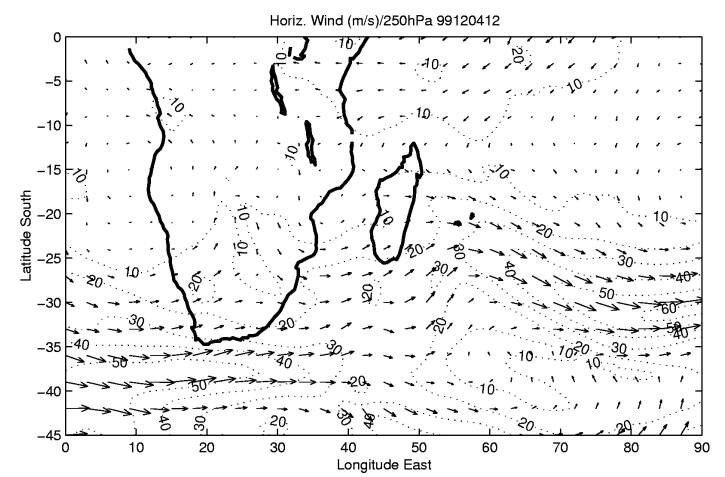

Fig. 2. Wind fields at $250 \mathrm{hPa}$ from ECMWF data showing the circulation patterns at the upper troposphere in the southern Africa and the adjacent for (a) 24 November, (b) 27 November, (c) 30 November, and (d) 4 December. 
a)

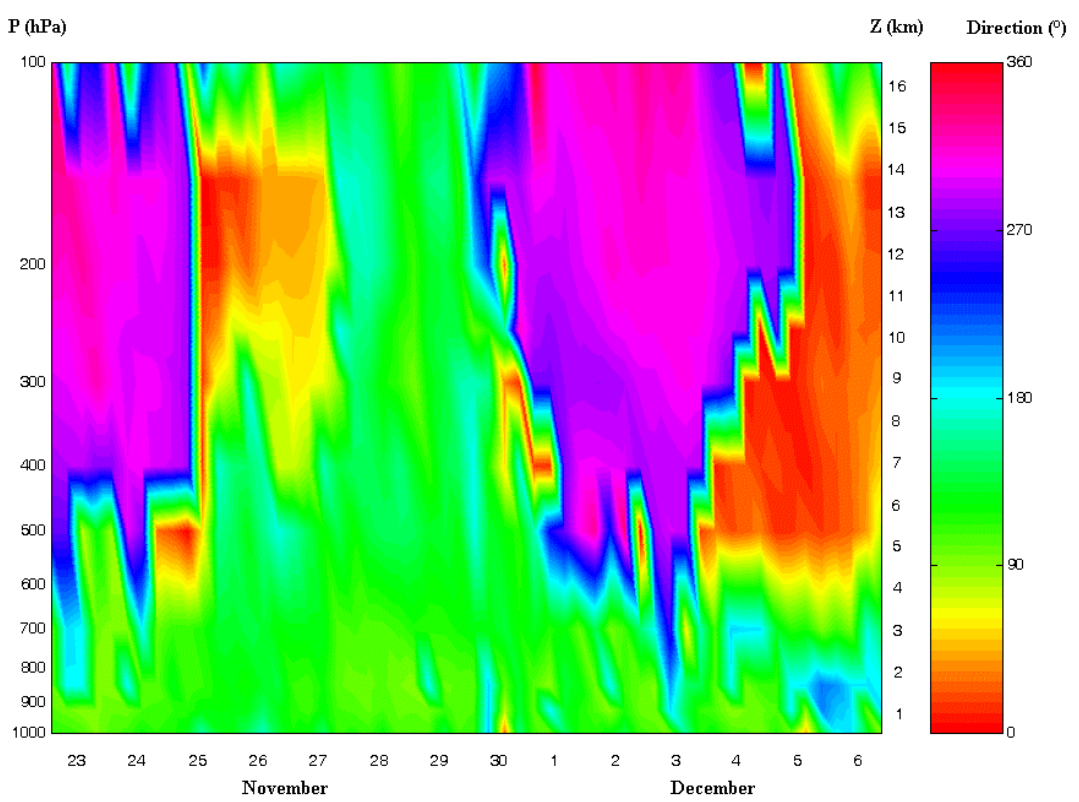

b)

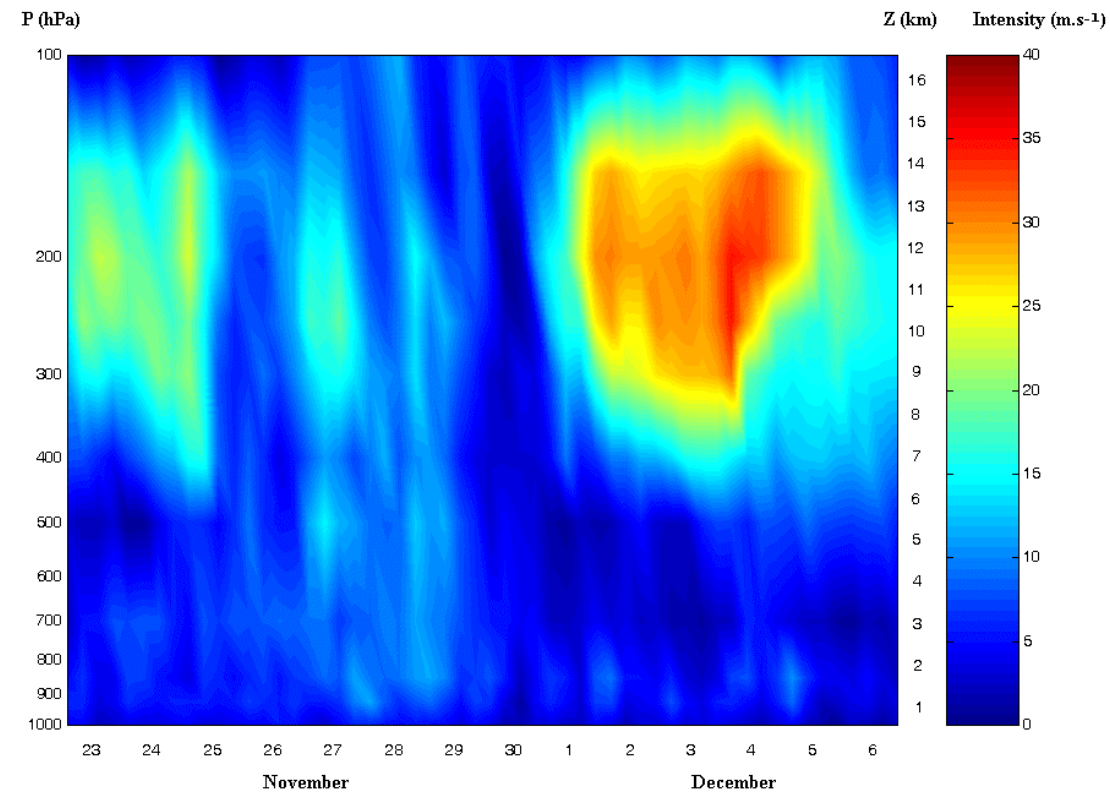

Fig. 3. (a) Horizontal wind direction (in degrees), and (b) intensity (in ${\mathrm{m} . \mathrm{s}^{-1}}^{\text {) }}$ over Reunion Island from 23 November to 6 December 1999. The direction $0^{\circ}$ means a wind direction toward east, $90^{\circ}$ toward north, $180^{\circ}$ toward west and $270^{\circ}$ toward south. The figure has been built from ECMWF with every $6 \mathrm{~h}$ outputs.

circulation which show passing ridge and trough sequences.

The meteorological data from ECMWF show that both wind fields at the surface level and at the high altitude show three different sequences of circulation. These results are in agreement with those obtained elsewhere (Preston-Whyte and Tyson, 1988; Garstang et al., 1996). These meteorological patterns can induce considerable day-to-day variability on the atmospheric circulation in southern Africa and the adjacent oceans, and consequently could affect the redistribution and transport of aerosols and trace gases.

\section{Tropospheric ozone at the end of the biomass burning season: measurements and analysis}

\subsection{Vertical ozone distribution}

In order to study the day-to-day ozone variation during the end of the biomass burning period, a continuous survey of ozone was undertaken during the period from 23 November to 6 December 1999. The ozone profiles from lidar measurements, presented in Fig. 4, show that daily con- 


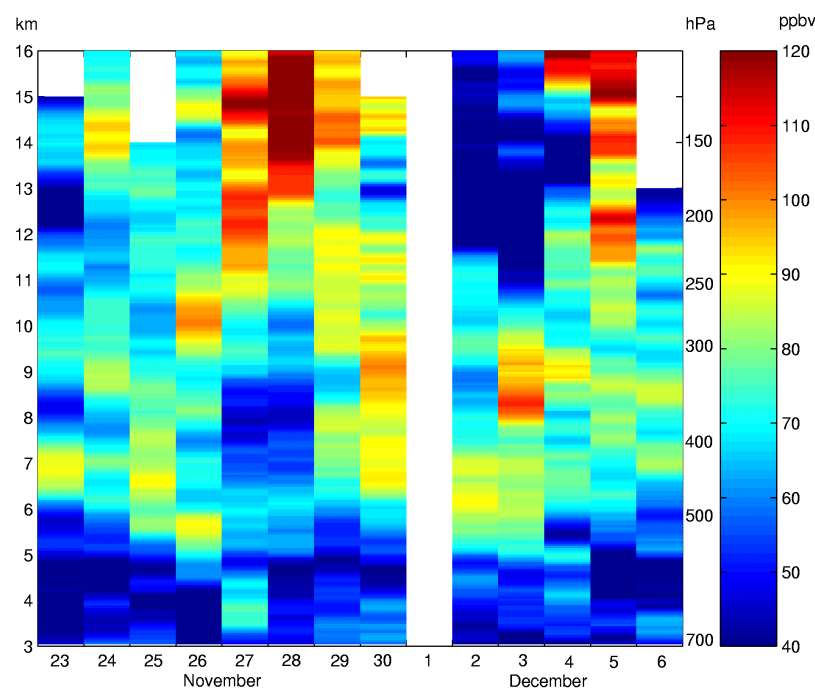

Fig. 4. Evolution of ozone mixing ratio (as a function of altitude in $\mathrm{km}$ ) over Reunion Island measured by lidar from 23 November to 6 December 1999. The color scale on the right gives values in ppbv.

centrations are in accordance with climatological profiles corresponding to the November-December period including bi-monthly (or less) ozonesondes (1992-1998) and weekly (or less) ozonesondes recorded from SHADOZ (1999-2001) (Fig. 5). Hence, the November-December 1999 campaign period corresponds to typical months.

Actually, the comparison of the averaged ozonesondes and lidar averaged ozone profiles show that both profiles present the same features with five distinct layers. Below $5 \mathrm{~km}$, the ozonesonde mixing ratios are larger than lidar. Above $5 \mathrm{~km}$, both profiles display an ozone increase, but lidar ozone mixing ratios are larger than the ozonesondes until $7 \mathrm{~km}$. Above $7 \mathrm{~km}$, there is a coincidence of diminution of ozone $(7.5-$ $8.5 \mathrm{~km}$ ) followed by an augmentation of ozone $(8.5-11 \mathrm{~km})$ for both profiles. Above, the two profiles decrease, and reach the minimum at different altitudes from 10 to $11 \mathrm{~km}$ for the ozonesondes and from 12 to $13 \mathrm{~km}$ for the lidar. Indeed, the decrease around $12 \mathrm{~km}$ was observed by the ozonesondes and lidar on 2 December.

During this period, the ozonesonde of 2 December (Fig. 6) displays the same ozone enhancement $(80 \mathrm{ppbv}$ between 6 and $11 \mathrm{~km}$ ) as the lidar profile obtained in the nighttime. The relative humidity profile shows high values below $3 \mathrm{~km}$, with moderately large values in the free troposphere. Humidity values observed within the free troposphere, between 3 and $10 \mathrm{~km}$ are concordant with the climatological profiles obtained during austral summer for Reunion station, presented in Baray et al. (1998).

The comparison of the seasonal picture based on ozonesonde observations and the continuous ground-based lidar observations shows large, standard deviation values (Fig. 5). Thus, high values of the lidar standard deviation show that the day-to-day variability is intense. It is to be noted further that the weekly SHADOZ measurements dis-

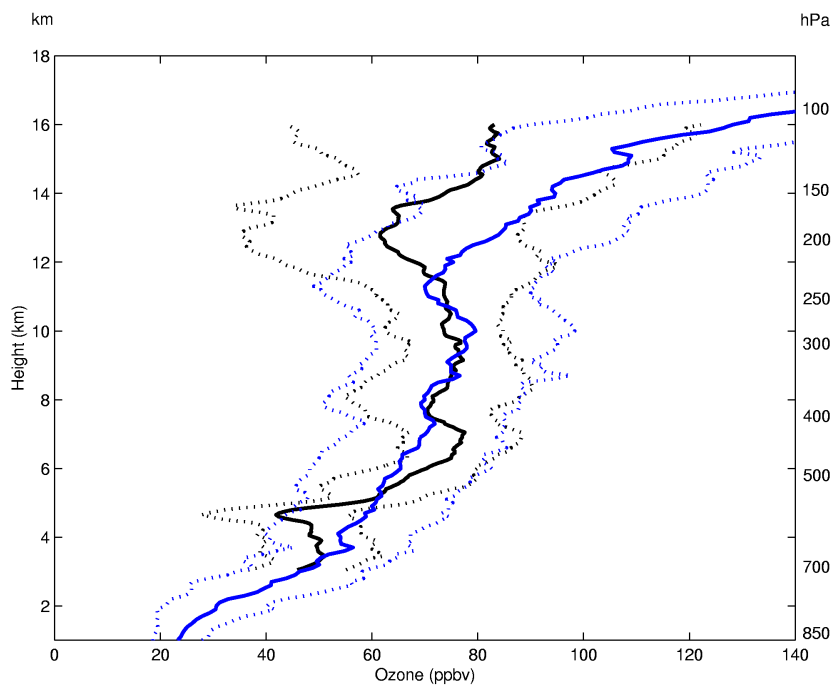

Fig. 5. Comparison of ozonesondes (bi-monthly or less 1992-1998, and weekly or less SHADOZ 1999-2001) (blue) and lidar (black) mean ozone profiles and the corresponding standard deviations.

play a strong variation of ozone mixing ratios (Thompson et al., 2003b), but some daily striking features are not observed during weekly measurements. Consequently, the day-to-day variability of ozone needs to be considered.

The lidar ozone mixing ratios show that ozone enhancements are observed in the whole free troposphere from $5 \mathrm{~km}$ (Fig. 4). The maximum enhancement (> $100 \mathrm{ppbv}$ ) is observed on 3 December 1999, where ozone enhancements are observed regularly in the free troposphere from 5 to about $11 \mathrm{~km}$. These ozone enhanced layers do not persist from one day to the following day, and display a high day-to-day variability of ozone mixing ratios. Ozone layers are very stratified on many days (especially 23 November, 26 November and 3 December), with thin layers ( 1 to $2 \mathrm{~km}$ thick) of very enhanced ozone mixing ratio (more than 30-40 ppbv, by comparison with adjacent ozone layers).

The stratification was not observed in the austral winter 1998 measurements from ozonesounding and lidar (Baray et al., 2000). Hence, it is interesting to compare the results of the austral summer of 1999 to the austral winter month July of 1998. During this period, an intensive measurement campaign was performed at Reunion Island and at Irene in South Africa.

Dynamical analysis showed the influence of planetary scale tropopause folds over the whole Indian Ocean (Baray et al., 2000). Figure 1 of Baray (2000) shows that, compared to the ozone enhancement during November-December 1999 , the ozone enhancement induced by these planetary tropopause folds during July 1998 appears to have almost the same intensity (about $70 \mathrm{ppbv}$ ) but is more confined in height, between 6 and $9 \mathrm{~km}$ height. The ozone increase observed during November-December is less localized at different heights in the free troposphere. 

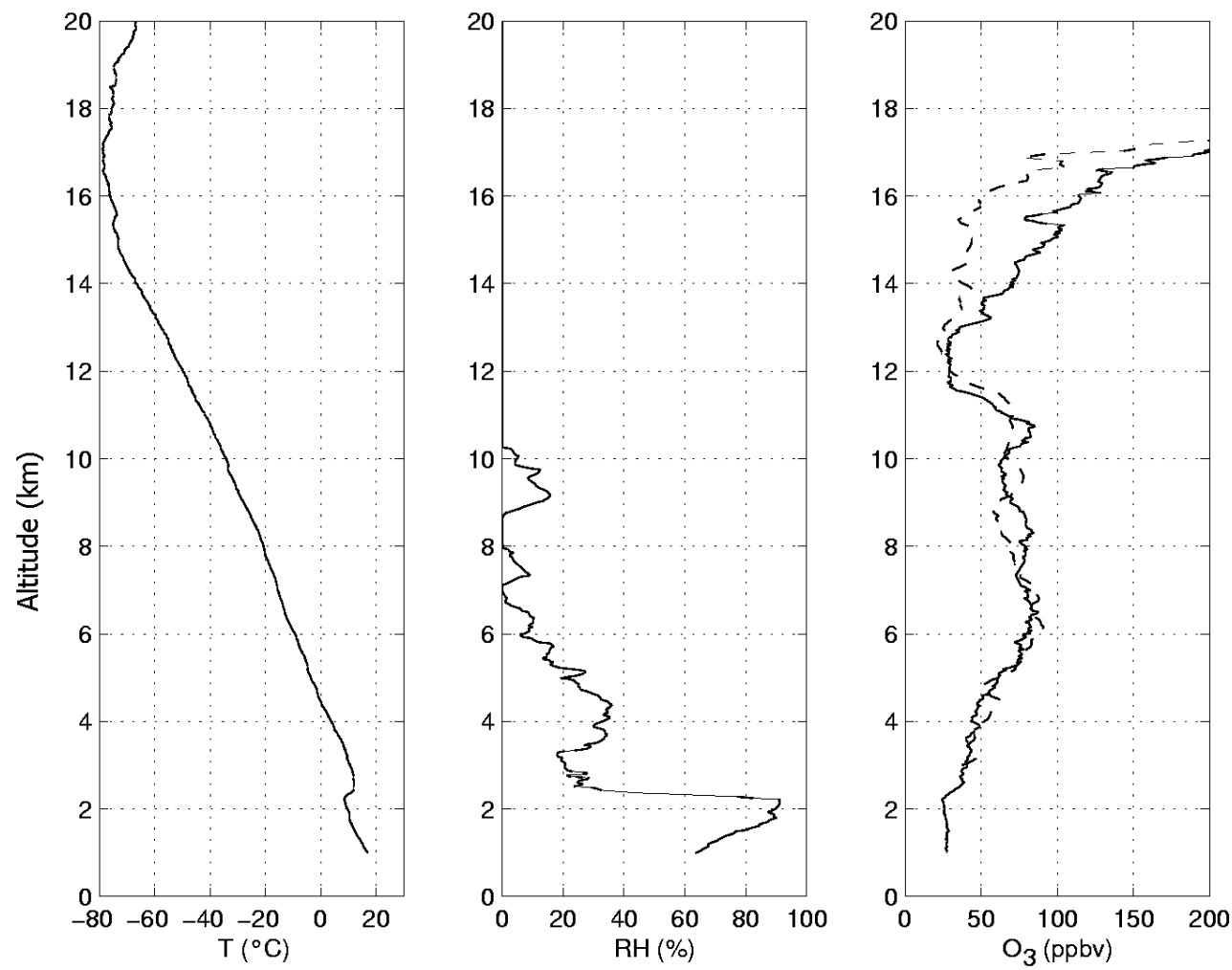

Fig. 6. Temperature (left), relative humidity (middle) and ozone mixing ratio (right) profiles obtained by ozonesounding on 2 December 1999, in the morning (continuous lines), and ozone mixing ratio profile obtained the same day at the end of the evening by lidar (dashed lines).

4.2 Comparison between the synoptic situations and vertical ozone distribution

The ozone profiles display three sequences in agreement with synoptic situations near source region and over Reunion Island. First, the 23-25 November period corresponds to the enhancement of ozone in the middle troposphere, which is in accordance to the winds that come from the northwest in the middle and upper troposphere. Second, the 26-30 November period corresponds to the enhancement of the upper tropospheric ozone and coincides with the strong westerly waves. The low ozone values ( $<50 \mathrm{ppbv}$ ) during $27-28$ November in the middle and low altitude correspond to ozone-poor midlatitude air masses, and the strong ozone values observed in the upper troposphere correspond to a stratospheric intrusion along the strong westerly wave. The ozone increase observed in the whole free troposphere on 30 November corresponds to a transition period for the middle latitude and the tropical influences in the middle troposphere. The third period from 2 to 6 December corresponds to the stronger values of ozone in the middle troposphere ( $>100 \mathrm{ppbv}$ ) and coincides with the shifting of the jet streak and the northerly winds. The ozone maximum observed on 3 December coincides with the presence of the jet streak over Reunion Island and the low ozone is associated with the northerly winds ( $<50 \mathrm{ppbv})$ in the upper troposphere (Fig. 7). For 4-5 December, the ozone peak and the decreased ozone tend to disappear, and the ozone profiles display a regular ozone enhancement with altitude resulting from the shifting of the northerly winds and the jet stream influences. During this period, tropospheric ozone amounts remain large (more than $110 \mathrm{ppbv}$ at $12 \mathrm{~km}$ height on 5 December).

\subsection{Biomass burning influence}

To determine the origin of the sampled air masses, back trajectories ending at Reunion were used. Back trajectories show that most of the enhanced ozone crossed over biomass burning regions of Madagascar and the southern African continent. The analysis of back trajectories during the study period found three different sequences of transports which are in agreement with the movement of synoptic situations. The 23 to 25 November period corresponds to air masses that cross over the north of Madagascar and the southern part of Africa (data not shown). The 26-30 November period corresponds to air masses coming from southern Africa and crossing over the mid-latitude regions (Fig. 8). From 2 to 6 December air masses cross over Madagascar and the southern part of Africa (Fig. 9). These results are corroborated by trade winds recorded at Reunion, indicating that northerly winds are predominant for the first period, southerly winds for the second period and westerly winds for the third period 


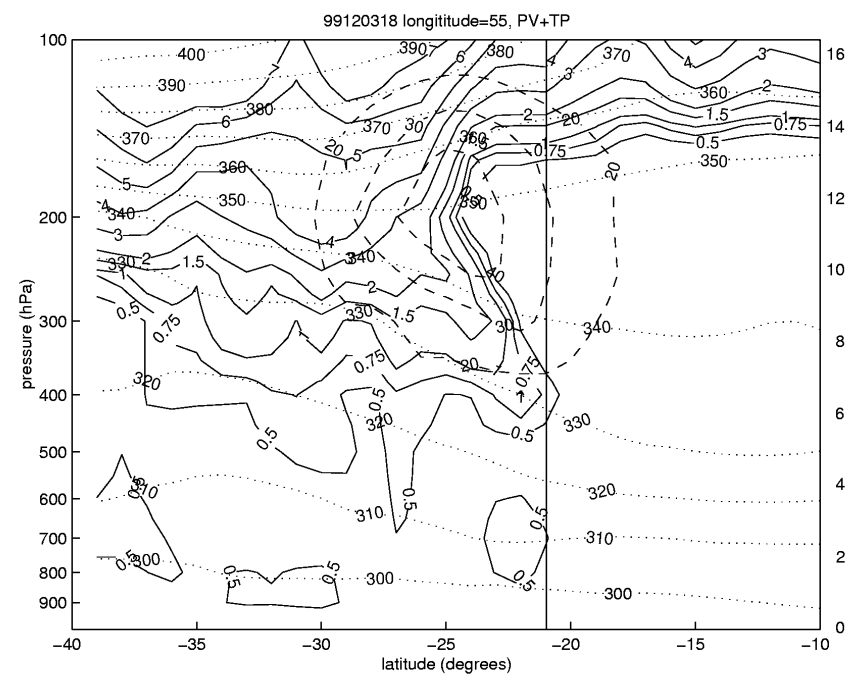

Fig. 7. Vertical longitudinal cross section of potential vorticity (in PVU, 1 PVU $=10^{-6} \mathrm{~m}^{2} \cdot \mathrm{s}^{1} \cdot \mathrm{kg}^{-1}$, solid lines), potential temperature (in $\mathrm{K}$, dashed lines) and horizontal wind (in $\mathrm{m} . \mathrm{s}^{-1}$, dotted lines) on 3 December 1999 at the longitude $55^{\circ}$ East. The latitude of Reunion Island $\left(21^{\circ} \mathrm{S}\right)$ is marked by a vertical black line (from ECMWF data).

in the middle and upper troposphere (Fig. 3).

The end of November corresponds to the end of the dry season and, hence, to the termination of traditional forest fires that generate extended smoke plumes visible over Madagascar more than $500 \mathrm{~km}$ downstream (Cahoon et al., 1992; Justice and al., 1996; Goldammer et al., 1996; Brivio and Grégoire, 1997; Randriambelo et al., 1998; and Arino et al., 2001). Large quantities of aerosols associated with biomass burning have also been observed in the Polder satellite data over the Indian Ocean near the Mozambique channel and Madagascar during the end of November (Deuzé et al., 1999).

During the period November-December 1999, total ozone from TOMS images indicates quite large ozone values in the study region (>295 DU) (Fig. 10). TOMS also evidences the interseasonal variability corresponding to a decrease in the TOMS data during December. Indeed, TOMS is influenced by the contribution of anthropogenic source in the tropics (Fishman et al., 1990). Hence, these observations further suggest that the observed ozone enhancement is likely to result from biomass burning emissions.

Moreover, during the interseasonal period in the latter part of biomass burning, deep convection is intensive, and through venting of ozone precursors, is likely to contribute to an ozone increase. Actually, during this period lightning is intense due to the presence of ITCZ over the southern Africa continent and Madagascar (Fig. 11). In addition, lightning could further enrich the upper troposphere in $\mathrm{NO}_{\mathrm{x}}$ (Pickering et al., 1996).
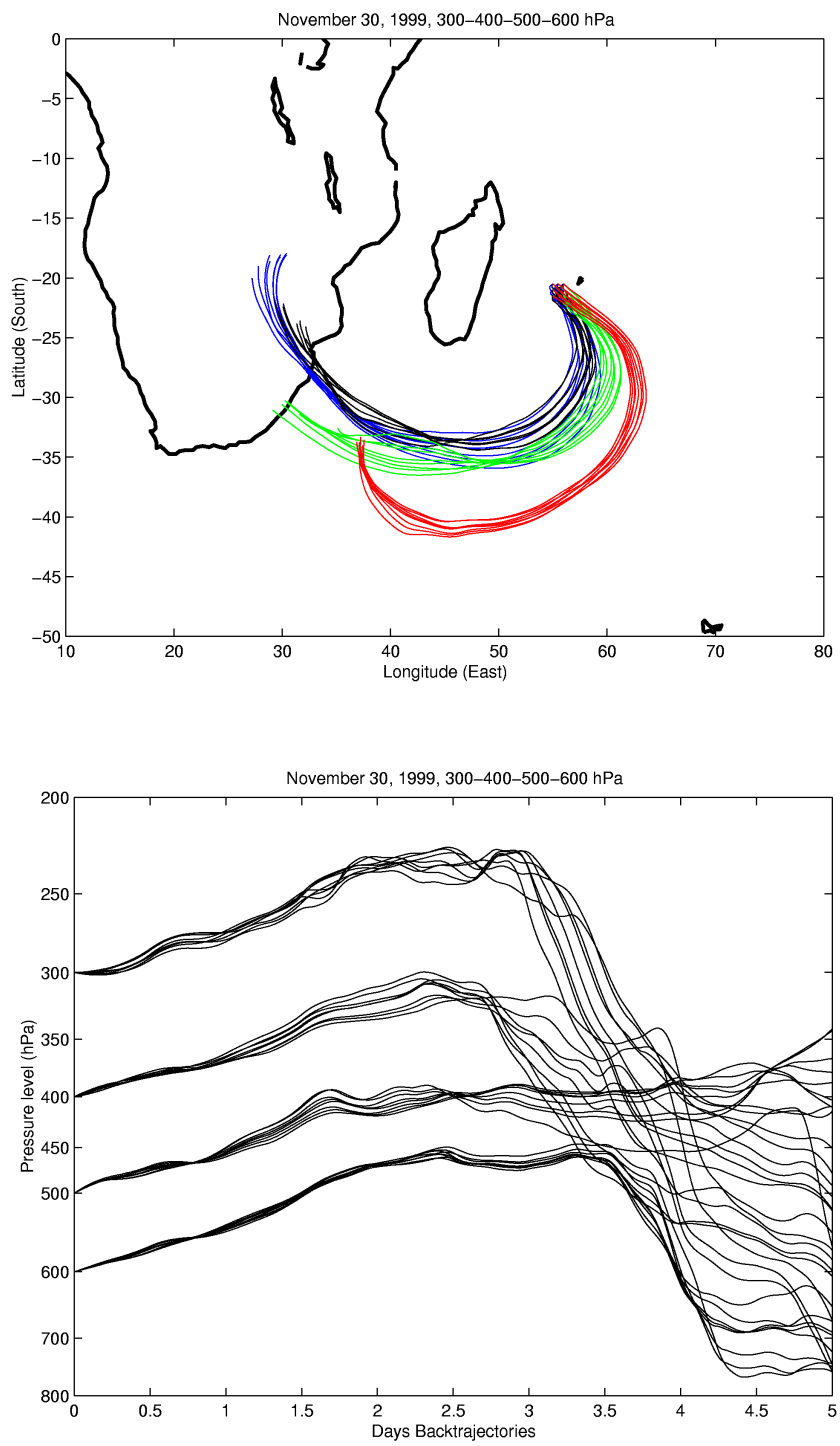

Fig. 8. Cluster back trajectories for 5 days (latitude range 20.5 to $21.5^{\circ} \mathrm{S}$, longitude range from 55 to $56^{\circ} \mathrm{E}$, ending on 30 November 1999, over Reunion Island (a) for different levels: $300 \mathrm{hPa}$ (blue), $400 \mathrm{hPa}$ (black), $500 \mathrm{hPa}$ (green) and $600 \mathrm{hPa}$ (red), and (b) altitude corresponding to these transports.

\subsection{Stratospheric influence}

Westerly disturbances are still observed in the end of the dry season and stratospheric contributions should be considered at Reunion Island. The evolution of potential vorticity (PV) (Fig. 12) calculated from ECMWF data show low PV values in the middle troposphere. Higher PV values in the upper troposphere suggests a stratospheric intrusion. A comparison between Fig. 4 and Fig. 12 suggests that stratospheric and anthropogenic influences coexist during this period. Indeed, Beekmann et al. (1994) showed, from a mid-latitude European data base, that a good correlation between PV and ozone mixing ratio in the free troposphere is a good indication of recent stratospheric intrusion into the troposphere. 


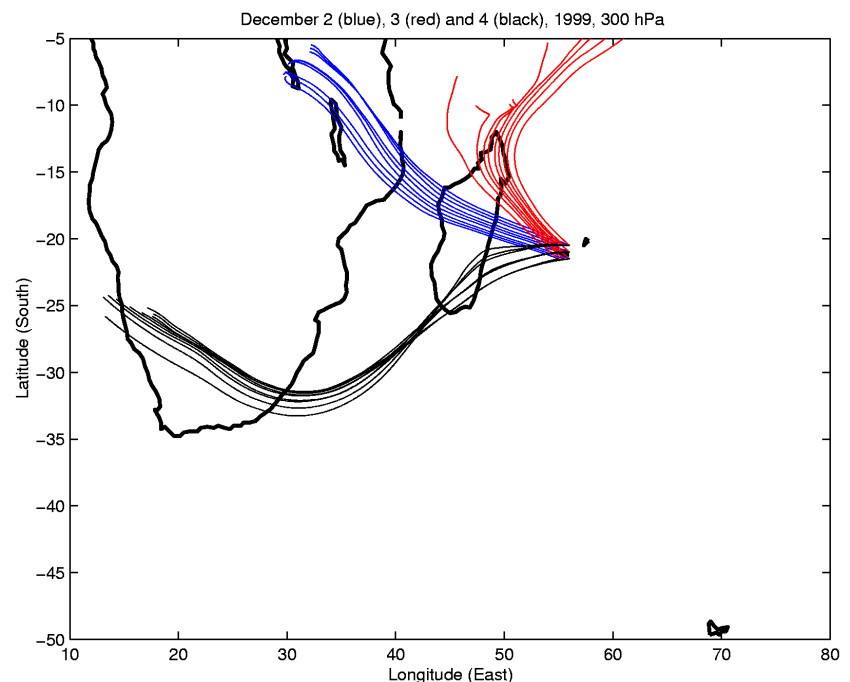

Fig. 9. As Fig. 8, cluster back trajectories for 3 days ending on 2 December (blue), 3 (red) and 4 (black) 1999, over Reunion Island, at $300 \mathrm{hPa}$ level, corresponding approximately to $9 \mathrm{~km}$ altitude.

Air masses characterized by high ozone concentrations, and weak PV values, are more likely to be influenced by anthropogenic sources like biomass burning, or other pollution.

On 30 November, the upper tropospheric $(300 \mathrm{hPa})$ ozone mixing ratio values are also consistent with higher potential vorticity, and the corresponding ozone profile could be influenced by a stratospheric intrusion. But this stratosphere troposphere exchange is not expected to be induced by the subtropical jet stream, which is very far from Reunion Island (Fig. 2c). In addition, winds are very low in the upper troposphere. It is further to be noted that back trajectories (above $500 \mathrm{hPa}$ ) indicate that air masses are coming from the southern African continent and cross over the mid-latitude regions (Fig. 8). After cloud venting near the source region, air masses undergo subsidence before reaching Reunion Island. Biomass burning and deep convection near source regions contribute to the ozone enhancement and westerly waves that enhance transport which exits the subcontinent to the east into the Indian Ocean (Garstang et al., 1996). Below $600 \mathrm{hPa}$, back trajectories show that air masses are coming from ozone poor regions to the mid-latitudes.

On 3 December, strong ozone values were observed (110 ppbv at $8 \mathrm{~km}$, more than 80 ppbv between 5 and $10 \mathrm{~km}$ ). Since the subtropical jet stream is localised at Reunion Island stratospheric intrusions are possible (Fig. 7). Strong ozone values observed over Reunion are not associated with high potential vorticity values, but we cannot exclude a stratospheric influence for this date. However, potential vorticity remains very weak over Reunion, compared to values for a typical subtropical fold (Baray et al., 2000). Since ozone values observed on 3 December 1999 are close to those observed on 16 July 1998, and since potential vorticity values are much lower than July 1998 records, stratospheretroposphere exchange is not likely to be the only source of
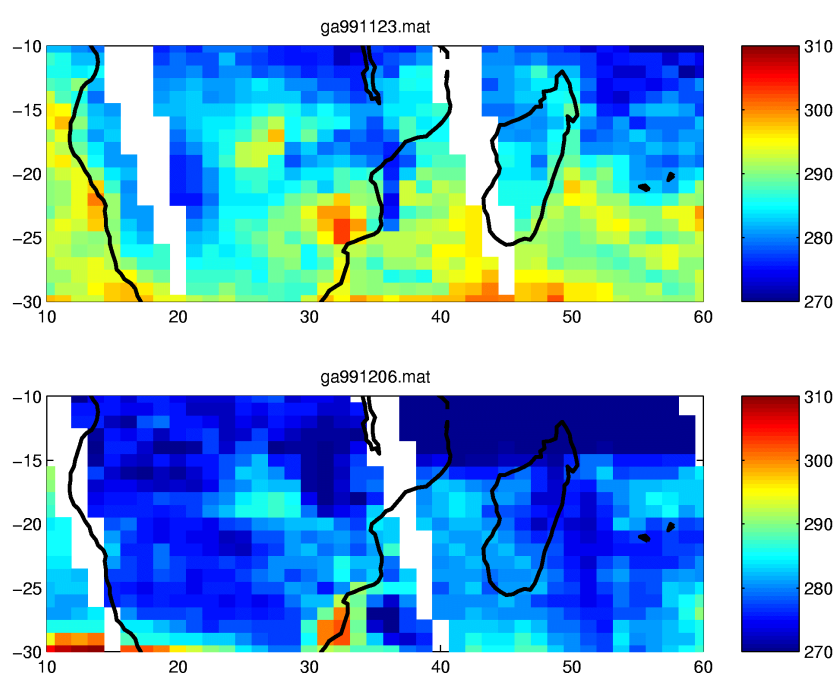

Fig. 10. Distribution of total ozone as measured by the TOMS instrument for 23 November 1999 (top) and 6 December 1999 (bottom). Data provided by web site at http//www.toms.gsfc.nasa.gov.

tropospheric ozone on 3 December 1999. Indeed, potential vorticity measured during July 1998 reached up to $1.25 \mathrm{PVU}$ (Baray et al., 2000). To better determine the different contributions, the analysis of ozone profiles around 3 December is of special interest.

Around $9 \mathrm{~km}$ altitude, ozone values on 2, 3, and 4 December are, respectively, $59 \mathrm{ppbv}, 108 \mathrm{ppbv}$ and $97 \mathrm{ppbv}$. Corresponding cluster back-trajectories starting from Reunion Island at $300 \mathrm{hPa}$ pressure level, approximately $9 \mathrm{~km}$ altitude, are given in Fig. 9. It is first to be noted that every clustertrajectory crosses a potential source zone of ozone precursors (Madagascar, eastern and southeastern Africa) and also a deep convection zone able to induce vertical transports of these precursors. Moreover, from one day to another, the source areas are expected to greatly vary. On 2 December, air masses cross over the centre of Madagascar and eastern Africa, then influenced by biomass burning. On 3 December, 4 December air masses are influenced by biomass burning, respectively, in the North of Madagascar and in the south of Madagascar and the southern Africa. During this sequence, the jet stream induces a strong enhancement of ozone in the middle troposphere on 3 December. After a few days, due to the displacement of the jet stream far from Reunion, the ozone peak disappears and conversely ozone in the upper troposphere increases. Hence, the influence of tropical convection is observed on 5 December which corresponds to a regular ozone profile enhancement. These results show that during one week from 30 November to 5 December, different contributions influence the ozone vertical distributions.

\section{Concluding discussion}

Since 1998, a ground-based tropospheric ozone lidar has operated at Reunion Island (Baray et al., 1999). A sec- 


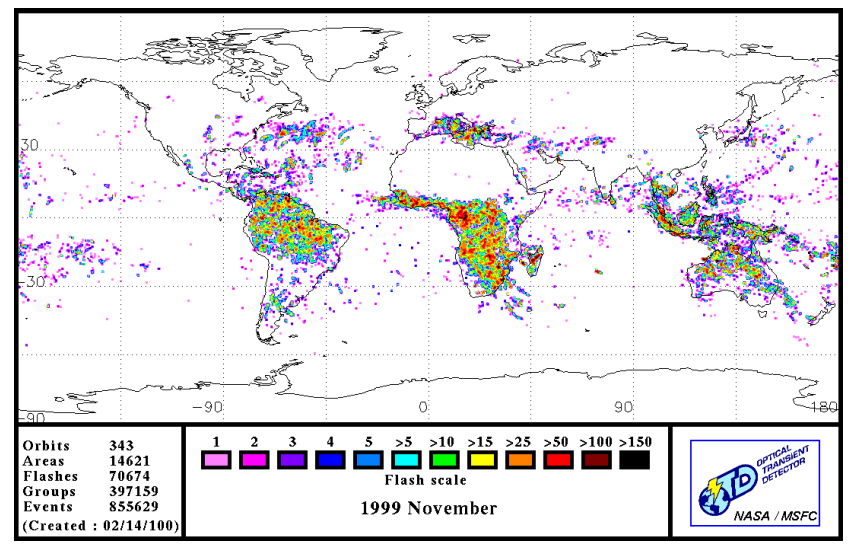

Fig. 11. Lightning data for November 1999 detected by the Optical Transient Detector. Data provided by web site at http://thunder.nsstc.nasa.gov/data.

ond lidar campaign has been performed during the end of the biomass burning season in November-December 1999. The averaged lidar ozone profile obtained during NovemberDecember 1999 is consistent with the averaged ozonesonde profile obtained during November-December from 1992 to 2001. Both the seasonal picture based on ozonesonde observations and the continuous ground-based from lidar observations show large standard deviations values. Although the week-to-week variability is intense, weekly measurement is not sufficient to characterize the day-to-day variability of ozone profile. The ozone profile responds to the nature of disturbances which vary from one day to the next.

The comparison of each daily ozone profile appeared very stratified compared to austral winter 1998 daily profiles; ozone maxima are observed at different heights within the whole free troposphere (from 5 to $16 \mathrm{~km}$ ). The dynamical context is different compared to July where the effect of the subtropical jet stream is predominant. The period of November-December coincides with the end of the dry season where biomass burning from forest fires is intense at Madagascar and with the onset of the rainy season characterized by numerous deep convective clouds. Back trajectories show that most of the enhanced ozone crossed over biomass burning and convection regions at Madagascar and the southern Africa continent.

Vertical ozone distributions during the observing period displays three sequences in agreement with the synoptic situations. First, the 23-25 November period corresponds to the enhancement of ozone in the middle troposphere, which is in accordance with winds that come from the northwest in the middle and upper troposphere. Second, the 26-30 November period corresponds to an enhancement of upper tropospheric ozone and coincides with the strong westerly waves. The 2-6 December period corresponds to stronger values of ozone in the middle troposphere, associated with the shifting of the subtropical jet stream and the northerly winds.

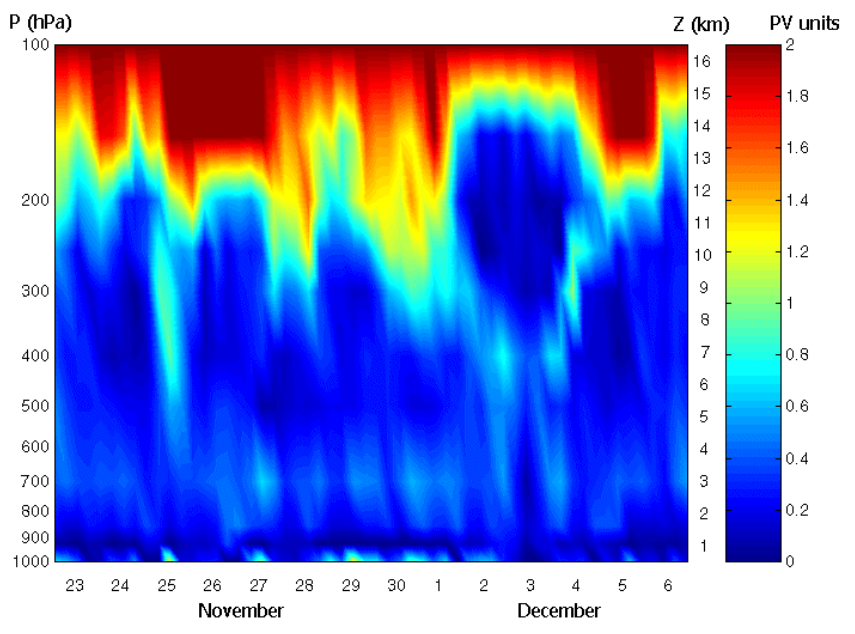

Fig. 12. Evolution of the profiles of potential vorticity as a function of pressure level, over Reunion Island from 23 November to 6 December 1999 from ECMWF data. The right scale shows the approximate correspondence between pressure levels and altitudes.

The vertical ozone distributions show daily stratification in agreement with disturbances that can vary greatly during a single week. For example, from 30 November to 5 December, ozone profiles display stratospheric intrusion, northerly influence, jet stream influences and convection, including passing ridge and trough disturbances. This study shows that because of the dynamical context and the frequent superposition of multiple ozone sources, the transport of aerosols and trace gases in the troposphere over southern Africa, Madagascar and adjacent oceans is conditioned by interacting planetary and synoptic-scale features of the general circulation of the Southern Hemisphere. Consequently, the impact of biomass burning over tropospheric ozone at Reunion Island, located far way from source regions, is actually not a steady ozone enhancement, but at the opposite, is composed of sporadic events with a large variability.

Acknowledgements. The lidar development at Reunion Island has been supported by CNRS/INSU and by the Conseil Régional de la Réunion. The technical implantation of the ozone lidar at Reunion Island has been supervised by Jacques Porteneuve and Gérard Ancellet (SA/CNRS), and we gratefully acknowledge the assistance of all the SA technical staff. Reunion ozonesoundings are supported by CNRS/INSU and NASA, under the responsibility of Françoise Posny and Jean-Marc Metzger. We are indebted to the ECMWF for providing model analyses, to the NASA/GSFC TOMS Ozone Processing Team (OPT) for providing satellite data, to the Global Hydrology and Climate Center at NASA for providing lightning data, and to the two reviewers for their comments which have improved the manuscript.

Topical Editor O. Boucher thanks two referees for their help in evaluating this paper.

\section{References}

Ancellet, G., Pelon, J., Beekmann, M., Papayannis, A., and Mégie, G.: Ground-based lidar studies of ozone exchange between the 
stratosphere and the troposphere, J. Geophys. Res., 96, 22 40122 421, 1991.

Andreae, M. O., Fishman, J., and Lindesay, J.: The Southern Tropical Atlantic Experiment (STARE): Transport and Atmospheric Chemistry near the Equator-Atlantic (TRACE A) and Southern African Fire-Atmosphere Research Initiative (SAFARI): An introduction, J. Geophys. Res., 101, 23 519-23 520, 1996.

Arino, O., Simon, M., Piccolini, I., and Rosaz, J. M.: The ERS-2 ATSR-2 World Fire Atlas and the ERS-2 ATSR-2 World Burnt Surface Atlas projects, Proceedings of the 8th ISPRS conference on Physical Measurement and Signatures in Remote Sens., 2001.

Bachmeier, A. S. and Fuelberg, H. E.: A meteorological overview of the TRACE-A period, J. Geophys. Res., 101, 23 881-23 888, 1996.

Baldy, S., Ancellet, G., Bessafi, M., Badr, A., and Lan Sun Luk, D.: Field observation of the vertical distribution of tropospheric ozone at the island of Reunion (Southern Tropics), J. Geophys. Res., 96, 23 835-23 849, 1996.

Baray, J. L., Ancellet, G., Taupin, F., Bessafi, M., Baldy, S., and Keckhut, P.: Subtropical tropopause break as a possible stratospheric source of ozone in the tropical troposphere, J. Atmos. Sol. Terr. Phys., 60, 27-36, 1998.

Baray, J. L., Leveau, J., Porteneuve, J., Ancellet, G., Keckhut, P., Posny, F., and Baldy, S.: Description and evaluation of a tropospheric ozone lidar implemented on an existing lidar in the southern subtropics, Appl. Opt., 38, 6808-6817, 1999.

Baray, J. L., Daniel, V., Ancellet, G., and Legras, B.: Planetaryscale tropopause folds in the southern subtropics, Geophys. Res. Lett., 27, 353-356, 2000.

Barbosa, P. M., Grégoire, J. M., and Pereira, J. M. C.: An algorithm for extracting burned areas from time series from AVHRR GAC data applied at a continental scale. Remote Sens. of Environment, 69, 253-263, 1999.

Beekmann, M., Ancellet, G., and Mégie, G.: Climatology of tropospheric ozone in southern Europe and its relation to potential vorticity, J. Geophys. Res., 99, 12 841-12 853, 1994.

Brivio, P. A. and Grégoire, J. M.: Spatial analysis of vegetation fire patterns : A multiannual rose diagram atlas fire for Africa, in Fire in Global Resource and Environmental Monitoring, Joint Research Center, Ispra, Italy, 1997.

Cahoon Jr., D. C. B., Stockst, J., Levine, J. S., Coffer III, W. R., and O'Neill, K. P.: Seasonal distribution of African savanna fire, Nature, 359, 812-815, 1992.

De Laat, A. T. J., Zachariasse, M., Roelofs, G. J., Van Velthoven, P., Dickerson, R. R., Rhoads, K. P., Oltmans, S. J., and Lelieveld, J.: Tropospheric $\mathrm{O}_{3}$ distribution over the Indian Ocean during spring 1995 evaluated with a chemistry-climate model, J. Geophys. Res., 104, 13881-13893, 1999. (Comments by Baray, J. L., Randriambelo, T., Baldy, S., and Ancellet, G., and reply by De Laat, A. T. J., and Lelieveld, J., J. Geophys. Res., 106, 1365-1370, 2001).

Diab, R. D., Jury, M. R., Combrik, J., and Sokolic, F.: A comparison of anticyclone and trough influences on the vertical distribution of ozone and meteorological conditions during SAFARI-92, J. Geophys. Res., 102, 23 809-23 821, 1996a.

Diab, R. D., Thompson, A. M., Zunckel, M., Coetzee, G. J. R., Combrik, J., Bodeker, G. E., Fishman, J., Sokolic, F., McNamara, D. P., Archer, C. B., and Nganga, D.: Vertical ozone distribution over southern Africa and adjacent oceans during SAFARI92, J. Geophys. Res., 102, 23 823-23 833, 1996 b.

Deuzé, J. L., Herman, M., Goloub, P., Tanré, D., and Marchand, A.: Characterization of aerosols over ocean from POLDER/ADEOS-
1, Geophys. Res. Lett., 26, 1421-1424, 1999.

Fishman, J., Watson, C. E., Larsen, J. C., and Logan, J. A.: Distribution of tropospheric ozone determined from satellite data, J. Geophys. Res., 95, 33 599-33 617, 1990.

Fuelberg, H., Van Ausdall, J., Browell, E., and Longmore, S.: Meteorological conditions associated with vertical distributions of aerosols off the west coast of Africa, J. Geophys. Res., 101, 24 105-24 116, 1996.

Garstang, M., Tyson, P. D., Swap, R., Edwards, M., Kallberg, P., and Lindesay, J. A.: Horizontal and vertical transport of air over southern Africa, J. Geophys. Res., 101, 23 721-2 736, 1996.

Goldammer, J. G., Pfund, J. L., Helfert, M. R., Lulla, K. P., and STS-61 Mission Crew: Use of the Earth observation system in the space shuttle program for research and documentation of global vegetation fires: A case study from Madagascar, in: Biomass Burning and Global Change, vol. 1, edited by Levine, J. S., MIT Press, Cambridge Mass, 236-240, 1996.

Justice, C. O., Kendall, J. D., Dowty, P. R., and Scholes, R. J.: Satellite remote sensing of fires during the SAFARI campaign using NOAA advanced very high resolution radiometer data, J. Geophys. Res., 101, 23 851-23 863, 1996.

Lacaux, J. P., Brustet, J. M., Delmas, R., Menault, J. C., Abbadie, L., Bonsang, B., Cachier, H., Baudet, J., Andreae, M. O., and Helas, G.: Biomass burning in the tropical savannas of Ivory coast: An overview of the field experiment fire of savannas (FOS/DECAFE'91), J. Atmos. Chem., 22, 195-216, 1995.

Marenco, A., Medale, J. C., and Prieur, S.: Study of tropospheric ozone in the tropical belt (Africa, America) from STRATOZ and TROPOZ campaigns, Atmospheric Environment, 24(A) 28232834, 1990.

Newell R. E., Thouret, V., Cho, J. Y. N., Stoller, P., Marenco, A., and Smit, H. G.: Ubiquity of quasi-horizontal layers in the troposphere, Nature, 98, 316-319, 1999.

Pickering, K. E., Thompson, A. M., Wang, Y., Tao, W. K., Mc Namara, D. P., Kirchhoff, V. W. J. H., Heikes, B. G., Sachse, G. W., Bradshaw, J. D., Gregory, G. L., and Blake, D. R.: Convective transport of biomass burning emissions over Brazil during TRACE-A, J. Geophys. Res., 101, 23 993-24 012, 1996.

Preston-Whyte, R. A., and Tyson, P. D.: The atmosphere and weather of Southern Africa, 374 pp., OXFORD University press Cape Town, 1988.

Randriambelo, T., Baldy, S., Bessafi, M., Petit, M., and Despinoy, M.: An improved detection and characterization of active fires and smoke plumes in south-eastern Africa and Madagascar, Int. J. Remote Sens., 19, 2623-2638, 1998.

Randriambelo, T., Baray, J. L., Baldy, S., Bremaud, P., and Cautenet, S.: A case study of extreme tropospheric ozone contamination in the tropics using in situ, satellite and meteorological data, Geophys. Res. Lett., 26, 1287-1290, 1999.

Randriambelo, T., Baray, J. L., and Baldy, S.: The effect of biomass burning, convective venting and transport on tropospheric ozone over the Indian Ocean: Reunion island field observations, J. Geophys. Res., 105, 11 813-11 832, 2000.

Stoller, P., Cho, J. Y. N., Newell, R. E., V. Thouret, Carroll, M. A., Albercook, G. M., Anderson, B. E., Barrick, J. D. W., Browell, E. V., Gregory, G. L., Sachse, G. W., Vay, S., Bradshaw, J. D., and Sandholm, S.: Measurements of atmospheric layers from the NASA DC-8 and P-3B aircraft during PEM-Tropics A, J. Geophys. Res., 104, 5745-5764, 1999.

Taupin, F. G., Bessafi, M., Baldy, S., and Bremaud, P. J.: Tropospheric ozone above the southwestern Indian Ocean is strongly linked to dynamical conditions prevailing in the tropics, J. Geo- 
phys. Res., 104, 8057-8066, 1999.

Taupin, F. G., Beekmann, M., Brémaud, P. J., and Randriambelo, T.: Ozone generation over the Indian Ocean during the South African biomass-burning period: case study of October 1992, Ann. Geophysicae, 19, 1-11, 2001.

Thompson, A. M., Pickering, K. E., McNamara, D. P., Schoelberl, M. R., Hudson, R. D., Kim, J.-H., Browell, E. V., Kirchoff, J. H., and Nganga, D.: Where did tropospheric ozone over Southern Africa and the tropical Atlantic come from in October 1992? Insights from TOMS, GTE/TRACE-A and SAFARI-92, J. Geophys. Res., 101, 24 251-24 278, 1996.

Thompson, A. M., Witte, J. C., McPeters, R. D., Oltmans, S. J., Schmidlin, F. J., Logan, J. A., Fujiwara, M., Kirchhoff, V. W. J. H., Posny, F., Coetzee, G. J. R., Hoegger, B., Kawakami, S., Ogawa, T., Johnson, B. J., Vömel, H., and Labow, G.: Southern Hemisphere Additional Ozoneson- des (SHADOZ) 1998-2000 tropical ozone climatology 1. Comparison with Total Ozone Mapping Spectrometer (TOMS) and ground-based measurements, J. Geophys. Res., 108, 8238, doi: 10.1029/2001JD000967, 2003a.

Thompson, A. M., Witte, J. C., Oltmans, S. J., Schmidlin, F. J., Logan, J. A., Fujiwara, M., Kirchhoff, V. W. J. H., Posny, F., Coetzee, G. J. R., Hoegger, B., Kawakami, S., Ogawa, T., Fortuin, J. P. F., and Kelder, H. M.: Southern Hemisphere Additional Ozonesondes (SHADOZ) 1998-2000 tropical ozone climatology 2. Tropospheric variability and the zonal wave-one, J. Geophys. Res., 108, 8241, doi: 10.1029/2002JD002241, 2003 b.

Zachariasse, M., Van Velthoven, P. F. J., Smit, H. G. J., Lelieveld, J., Mandal, T. K., and Kelder, H.: Influence of stratospheretroposphere exchange on tropospheric ozone over the tropical Indian Ocean during the winter monsoon, J. Geophys. Res., 105, 15 403-15 416, 2000. 